\title{
Mário de Andrade no Café
}

\author{
FLÁVIA CAMARGO TONI \\ e MARCOS ANTONIO DE MORAES
}

"Nem todo o trigo do universo feito pão
Acalmava esta fome antiga e multiplicada
Fome de fome”

Mário de Andrade, Café

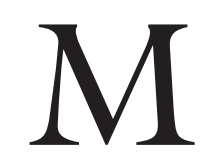

ÁRIO DE ANDRADE moderno e modernista, ao longo de toda a sua obra de artista, crítico e historiador preocupou-se com seu papel na humanidade e sua função na História. Essa preocupação marca fortemente Café, uma "tragédia secular" em forma de ópera, no momento em que, já superado o modernismo de programa, repensa o papel social da arte.

Passada a euforia do primeiro tempo modernista, os anos 30 procuram redefinir a questão da modernidade na literatura e nas artes. Oswald de Andrade, em 1933, ao publicar Serafim Ponte Grande, pondera: "A valorização do café foi uma operação imperialista. A poesia pau-brasil também. Isso tinha que ruir com as cornetas da crise. Como ruiu quase toda a literatura 'de Vanguarda', provinciana e suspeita, quando não extremamente esgotada e reacionária. Ficou da minha este livro". É importante, pois, constatar que o mesmo café, "mecenas" e patrocinador da geração "sarampão antropofágico", traz com o próprio declínio e crise o fim do primeiro modernismo em 1929, após a guerra da bolsa de Nova York e o conseqüente comprometimento de toda a estrutura da "semicolônia". Data de 1933 o primeiro esboço da Ópera Café e a poesia de $A$ costela do GrãoCão, quando cresce a voz do poeta profeta, demolindo ilusões e clamando por um tempo novo.

O texto de Café passará por várias redações, sendo a última de dezembro de 1942. Em 1939, vivendo no Rio de Janeiro, Mário acha o parceiro musical no amigo e compositor Francisco Mignone. O projeto, todavia, não se completará musicalmente. Dividido em "Concepção melodramática" e "Tragédia secular" (o poema), Café, dedicado a Liddy Chiafarelli, mulher de Mignone, aparecerá em Poesias completas em 1955, 10 anos depois da morte de Mário de Andrade. Tendo referências imediatas a fatos históricos, o texto/poema correria perigo de se tornar panfletário, se 
o autor não tivesse trabalhado cuidadosamente o sentido simbólico da crise do café. Constata Victor Knoll (Paciente arlequinada) que um juízo de valor muito forte acaba por sublimar a obra: a crença utópica em um "Dia Novo", melhor, comunitário e humano.

Em novembro de 1943, decorridos 11 meses da conclusão de Café, Mário, em dois artigos de sua coluna Mundo Musical - "Do teatro cantado" e "Psicologia da criação" - na Folha da Manhã, conta a gênese do libreto. No primeiro, relata a conversão daquele que, na imprensa, tanto se opusera à ópera e, no segundo, destaca a "idéia criadora" do texto de Café.

A conversão se dera em 1933, quando a agenda musical da cidade de São Paulo estava lotada de apresentações de óperas montadas por companhias líricas italianas e brasileiras. Mário, como crítico musical, se aborrecia com o número de encenações a que devia comparecer, devendo mesmo suportar a má qualidade de algumas. Naquele momento começara a pensar mais detidamente sobre a ópera: “(...) aos poucos os problemas do teatro cantado se impunham a mim, me empolgavam, eu já não ria mais, eu não desprezava mais ninguém, e ao mesmo tempo que, embora ainda desconfiado, eu me convertia à ópera como valor estético, me perseguia como prodigiosamente grava a importância social dela." Cumpria pois, revitalizar o gênero em função da escolha de assuntos contemporâneos "que tivessem para nós o mesmo interesse e a mesma possibilidade de coletivização e ensinamento. O café! A imagem pulou. Não seria possível acaso tentar uma ópera de interesse coletivo, tendo como base de assunto o café?..."

“Seria sim!” E ele, Mário de Andrade, o poeta que, em 1922, já era grande conhecedor da múscia e havia publicado, em Paulicéia desvairada, "As enfibraturas do Ipiranga", um “oratório profano", em 1933 tomava para si o encargo de uma ópera de interesse coletivo centrada na crise do café. E moderno, arrojado, acreditava em uma originalidade maior, ao escrever exclusivamente para coros, eliminando os virtuoses, ou seja, desenvolvendo "personagens corais".

Encontrava uma forma de banir o virtuosismo de palco, preso a heróis e heroínas representados por primas-donas e tenores malabaristas, que detestava. Pretendia levar ao extremo aquilo que o Guilherme Tell de Rossini, que Verdi nas Vésperas sicilianas, na Aida e no Nabuco ou Boris Gudonov de Mussorgski haviam inaugurado: a transferência da narrativa para grupos corais, a "ópera de interesse coletivo", cantada enquanto representação do povo. E para evitar a monotonia coral, buscava solução no jogo de timbres e volumes vocais alternando vozes mistas, masculinas e femininas, combinadas em madrigais e tutti. 
Quanto ao assunto - Mário recapitula a eclosão do projeto - o café, tão familiar aos brasileiros, não seria explorado a partir de sua experiência de jornalista que presenciara a crise de 1929 e a revolução de 30. Queria, isto sim, retomar a idéia do "princípio místico de morte e ressurreição" de deus da natureza, do sustento tribal, "mito na raiz de tantas culturas, desde a Grécia Antiga". E como esse princípio persiste "na base das próprias formas econômicas e institucionais das sociedades", a economia paulista oscilava em função da "morte e ressurreição ânua do café". A partir do momento em que o produto baixasse de preço no mercado, a insatisfação pública geraria a revolta exigindo a mudança de regime.

Surgira assim o enredo "com muita lógica conclusiva": três atos, culminando com o triunfo da revolução. Café, segundo o autor, vai expressar os "sofrimentos verdadeiros" e a quebra do jogo, quando as massas oprimidas renascerem no "Dia Novo", livres de fome, em um mundo onde as desigualdades sociais inexistem, porque, havendo união não haverá fracasso; mundo onde o individual é substituído pelo social. No primeiro ato, tanto no porto, como no campo, as massas corais, estivadores e colonos externam sua impotência perante "os donos da vida", a ópera denunciando as condições de penúria e opressão daqueles que dependem do café; trazendo já o ânimo de resposta e resistência das mulheres. No "Coral das famintas", as mulheres dos estivadores incitam à luta; na voz das colonas vem: "O homem não é propriedade do homem", verso marcado no texto como citação.

No segundo ato, formado pelas cenas da Câmara dos deputados e do êxodo, a intenção é confrontar abastados e desvalidos. Os primeiros sempre usando o palavreado vazio e os segundos, a linguagem do medo e da necessidade. Nos apelidos, deputado do Som-Só, deputadinho da Ferrugem, deputado Cinza, e nos papéis que lhes cabem, o sarcasmo se afirma. A indiferença dos deputados é compartilhada pela dos jornalistas; na Câmara, nada se discute de útil. Os protestos da galeria criando tumulto precedem a entrada da Mãe, o momento mais trágico do libreto. O deputado Cinza, populista e manipulador, tenta fazer com que a Mãe derrame esperança sobre os desesperados, no discurso por ele escrito, que ela não logra decorar. A Mãe se lança então na "Endeixa" em que delira e expande o discurso da angústia e da dor. Encarna todas as mães do mundo; torna-se uma espécie de arquétipo do sofrimento milenar, quando se apropria do canto da Verônica: "Falai si há dor que se compare à minha!..."

O terceiro ato, "Dia Novo", apresenta, em cena única, a revolução, a vitória sobre o "presidente Papai Grande" e os "gigantes opressores". Na apoteose final, em um grande quadro móvel, o "Hino à fonte da vida" une: 
"força!... amor!... trabalbo!... paz!..."

Como se vê, a tensão dramática que cresce no decorrer dos três atos só é rompida em uma única e eficaz cena cômica. Mário dá sua explicação, em 1943 ("Do teatro cantado"), quando focaliza a diferença entre o imaginar e o escrever, pois, no passar dos anos, muita coisa mudara em sua ópera coral. Em um determinado momento, diante do excesso de gravidade na predominância dos coros masculinos, entendera que deveria desfatigar $\mathrm{o}$ público dando-lhe a pândega de "Câmara de ballet", uma sátira às câmaras de deputados. Associara-se então às soluções do Ballet Joos, da moderna dança sueca, cujo espetáculo, Table Verte, o havia deslumbrado em 1940.

Entusiasma saber que Café chega finalmente ao palco e recebe a música de Koellreutter. Cabe lembrar que, nos anos 60, a montagem teatral por estudantes universitários foi proibida pela censura; ameaçava o "regime, a ordem pública e as autoridades". Esse tempo sem sol tudo fez par sufocar a crença em um "Novo Dia", reiterada nos festivais de música, como estuda Walnice Nogueira Galvão em "MPB: uma análise ideológica".

Conhecida na leitura, a “concepção melodramática” de Café nos surpreende pela visão de cenografia, de marcação de cena, e nos dá a certeza de que o autor ouvia/construía a música que não viu concretizada na partitura. E o poema nos emociona; nos empolga. Quando, no jornal e na TV, testemunhamos o perambular de todos os sem-terra e sem-teto, no Brasil e no mundo, escutamos a Mãe que repete:

"Falai!...

Falai si há dor que se compare à minha!...”

Flávia Camargo Toni é pesquisadora na área de Música.

Marcos Antonio de Moraes é doutorando em Literatura Brasileira pela FFLCH-USP. 